\title{
TURYSTYKA I REKREACJA - FORMA AKTYWNOŚCI FIZYCZNEJ OSÓB STARSZYCH
}

\begin{abstract}
Streszczenie
W współczesnym świecie coraz większego znaczenia nabiera kwestia zdrowotności starzejącego się społeczeństwa. Zaczynamy doceniać znaczenie aktywności fizycznej w odniesieniu do kondycji zdrowotnej społeczeństwa. Pojawia się znacząca liczba różnorodnych form aktywności adresowanych dla seniorów. Jedną z nich jest turystyka, będąca najczęściej spotykaną formą rekreacji, w tym w szczególności rekreacji fizycznej. W opracowaniu przedstawiam teoretyczne aspekty znaczenia rekreacji i turystyki dla zdrowia seniorów.
\end{abstract}

Słowa kluczowe: rekreacja, turystyka, aktywność fizyczna, seniorzy

\section{Wstęp}

Aktywność to pojęcie coraz popularniejsze w naszej rzeczywistości. Dla wielu osób to synonim dobrego, udanego i zdrowego życia. W literaturze przedmiotu znajdujemy wiele jej określeń. Jedno z nich ujmuje aktywność jako „właściwość indywidualną jednostki polegającą na większej niż u innych częstości i intensywności jakiegoś działania” (Okoń, 1996, s. 17). Można ją rozumieć „jako synonim życia, stały i dostosowany do możliwości danej osoby wysiłek lub też jako warunek prawidłowego rozwoju, umożliwiający prowadzenie twórczego i harmonijnego życia” (Rynkowska, 2019). Jest ona warunkiem prawidłowego rozwoju, umożliwia prowadzenie twórczego i harmonijnego życia, jest podstawą leczenia wielu chorób, opóźnia procesy starzenia się. Warto zwrócić uwagę na fakt, że podejmując różnorodne formy aktywności, człowiek czuje się wolny, ma poczucie niedokończo- 
ności, czuje się potrzebny, daje innym powód do dalszego, pełnego pozytywnych aspektów życia.

W różnych opracowaniach pojawiają się następujące rodzaje aktywności: hobbystyczna; edukacyjna; twórcza; rodzinna; kulturalna; społeczna czy fizyczna.

Ten ostatni rodzaj aktywności, czyli aktywność fizyczna, jest traktowany jako nieodłączny atrybut życia człowieka. W znaczącym stopniu wynika z wrodzonych potrzeb organizmu i nabytych umiejętności. Jest niezbędnym elementem zdrowego stylu życia, a także poprawia stan naszego zdrowia i samopoczucie. „W wielowymiarowym życiu współczesnego człowieka powinno pojawić się nieustające kształcenie, także w zakresie wartości tkwiących w kulturze fizycznej. To najbardziej interesujący nas obszar ludzkiej egzystencji” (Madejski, Węglarz, 2008, s. 117). Warto zwrócić uwagę na konieczność realizacji permanentnej kultury fizycznej, czyli procesu, który nie ustaje z chwilą zakończenia szkoły, ale trwa przez całe życie. W tym kontekście bardzo ważne jest stworzenie warunków do realizacji dobrowolnego uczestnictwa w aktywności fizycznej osób w różnym wieku, w szczególności seniorów.

Aktywność fizyczna w dużym stopniu wpływa na funkcjonowanie organizmu: poprawia krążenie krwi, pomaga w kontrolowaniu ciśnienia tętniczego oraz obniża poziom cholesterolu. Ma wpływ na utrzymanie prawidłowej masy i elastyczności ciała, prawidłowej kondycji kości i stawów, kształtuje prawidłową postawę, wzmacnia wytrzymałość i siłę mięśni, przez co powoduje zwiększenie poziomu sprawności fizycznej, dodaje energii. W znacznym stopniu wpływa także na obniżanie ryzyka chorób serca, raka okrężnicy i cukrzycy typu II, czy też odczuwania depresji i lęków. Warto także zauważyć, że aktywność fizyczna podwyższa poczucie własnej wartości każdego człowieka oraz poprawę jego samopoczucia.

Rekreacja i turystyka jako formy aktywności fizycznej są bardzo ważnym elementem w podwyższaniu wydolności fizycznej starszego człowieka, w poprawianiu jego kondycji zdrowotnej i psychicznej. „Wieloletnie badania wskazują, że większą umieralnością charakteryzują się osoby z najniższą wydolnością fizyczną. To czy człowiek jest sprawny na starość zależy m.in. od trybu życia, jaki prowadził, a także aktywności fizycznej w latach młodzieńczych i dojrzałych" (Gierat, 2013, s. 91-92). Rozwijanie i utrzymywanie sprawności fizycznej jest możliwe w każdym wieku. Warto uświadomić sobie konieczność podejmowania działań prowadzących do dbania o siebie i swoje zdrowie. Należy tylko pamiętać, aby formy rekreacyjne dostosować do wieku, możliwości fizycznych, psychicznych i zdrowotnych, do własnych zainteresowań i oczekiwań. 


\section{Rekreacja}

Z pojęciem aktywności fizycznej bardzo blisko koresponduje pojęcie rekreacji. W wielu opracowaniach pojęcia te są tożsame, oznaczając ten sam zakres działań i zbliżoną specyfikę.

„Rekreacja (z łac. recreatio), to forma działania wybrana dobrowolnie przez człowieka ze względu na osobiste zainteresowania i dla odpoczynku, rozrywki lub rozwoju własnej osobowości; podejmowana poza obowiązkami zawodowymi, społecznymi i domowymi, w czasie wolnym od pracy" ${ }^{\prime *}$. W Polsce termin ten zaczął funkcjonować w XVI wieku i był tożsamy z przerwą podczas wykonywania jakichś obowiązków i z zajęciami służącymi odpoczynkowi. Od początku zatem rekreacja była powiązana z pewną formą aktywności, z odpoczynkiem od obowiązków, ale nie oznaczała bezczynności. W XIX w. używano tego terminu jako zamiennika wyjazdów do uzdrowisk w celach zdrowotno-wypoczynkowych (Winiarski, 2011, s. 16). Jak wynika $z$ analizy literatury przedmiotu, pojęcie rekreacji stosowano jako odpowiednik urlopu, wypoczynku, wczasów, utożsamiano ją z czasem wolnym.

W literaturze pojawiają się następujące formy rekreacji:

$>$ turystyczna, czyli turystyka aktywna o różnym charakterze: piesza, nizinna i górska, rowerowa, narciarska, żeglarska, kajakowa;

$>$ sportowa, obejmująca sporty rekreacyjne, np. pływanie, tenis, golf, jazda konna itp.;

> hobbystyczna, związana z działalnością amatorską, np. wędkowanie, grzybobranie;

towarzyska, koncentrująca się np. na tańcu czy grach i zabawach towarzyskich;

$>$ kulturalno-rozrywkowa, czyli amatorska twórczość artystyczna oraz pobytowa, np. pobyt w wesołym miasteczku, parku rozrywki;

$>$ wirtualno-interaktywna, realizowana poprzez gry internetowe (tamże, s. 16).

Przyjmując za kryterium podziału rodzaje zainteresowań i związane z nimi czynności, które są podejmowane w czasie wolnym, Joffre Dumazedier wyróżnia rekreację: fizyczną, praktyczną, artystyczną, umysłową lub rekreację, natomiast Alain Corbin: ruchową, hobbystyczną, kulturalną oraz rekreację obejmującą mieszane rodzaje działalności. Kazimierz Czajkowski dzieli rekreację na: twórczą, fizyczną, kulturalno-rozrywkową oraz rekreację poprzez działalność społeczną. Jednak niezależnie od klasyfikacji rekreacji, wszystkie one wyróżniają rekreację ruchową, alternatywnie nazywaną rekreacją fizyczną (Żukrowska, 2006, s. 175).

Teresa Wolańska pod pojęciem rekreacji fizycznej rozumie „te wszystkie zajęcia o treści ruchowo sportowej lub turystycznej, którym człowiek oddaje się z własnej

\footnotetext{
* https://encyklopedia.pwn.pl/haslo/rekreacja;3966939.html, dostęp z dn. 25.10.2019.
} 
chęci w czasie wolnym od obowiązków, dla wypoczynku, rozrywki i dla rozwoju własnej osobowości" (tamże, s. 175). Jak podaje autorka, jest to aktywność dobrowolna podejmowana w celach: wypoczynkowych, hedonistycznych, zdrowotnych, edukacyjnych, towarzyskich. Rekreacja fizyczna to pomost łączący kulturę fizyczną oraz kulturę czasu wolnego. Różne definicje rekreacji, które znaleźć możemy w literaturze, łączy to, że zawierają takie elementy rekreacji jak: aktywność (fizyczna, psychiczna, społeczna, emocjonalna); dobrowolne uczestnictwo; wewnętrzna motywacja uczestników; pożądane rezultaty: przyjemność, zadowolenie, satysfakcja (Winiarski, 2011, s. 14).

Decydujący wpływ na to, czy dana czynność jest rekreacją, ma postawa i stan umysłu człowieka, a nie wybrana przez niego forma aktywności. Mimo faktu, że uprawianie rekreacji to źródło satysfakcji i radości, to może ona polegać także na udoskonalaniu siebie, czego wynikiem może być polepszenie sprawności psychofizycznej, zdrowotnej oraz jakości życia człowieka. Warto zaznaczyć, iż o rekreacyjnym charakterze danej czynności nie decyduje jej forma, ale podmiotowa ocena osoby, która wykonuje tę czynność. Bowiem ta sama czynność może być w jednym przypadku dobrowolna i traktowana rekreacyjnie, a w drugim może być obowiązkowa i traktowana jako praca.

Jedną z ciekawszych form aktywności ruchowej i rekreacji jest zabawa, „która poprzez bogactwo form i niekonwencjonalne rozwiązania stwarza możliwość projektowania zajęć dla osób w starszym wieku. Seniorzy korzystający z oferty zajęć o charakterze zabawowym, znajdą zapewne coś, co w szczególny sposób będzie odpowiadało ich możliwościom, będzie wychodziło naprzeciw ich zainteresowaniom i zdolnościom" (Banach, Banach, 2015a, s. 192). Wskazując zalety tej formy rekreacji warto wymienić takie jak: wyrażanie uczuć, radzenie z emocjami, okazja do komunikowania, rozładowanie napięć, doskonalenie sprawności ruchowej, współżycie w grupie itd." (Banach, Banach, 2015b, s. 171).

Ewelina Zdebska zauważa, że osoby starsze mówiąc o głównych celach aktywizacji fizycznej, w tym zakresie także rekreacji, wskazują na następujące:

„- utrzymanie sprawności fizycznej i zdrowotnej;

- usamodzielnienie, pobudzenie zaradności;

- nauka współżycia w grupie i środowisku;

- utrzymanie/obudzenie wiary w sens życia;

- rozwijanie różnych zainteresowań;

- stymulowanie procesów wyobrażeń i twórczego działania;

- rozwijanie osobowości” (Zdebska, 2014, s. 41-42).

Rekreacja jako forma aktywności ruchowej pozwala na ciekawsze, pełne wrażeń, wzruszeń, okraszone odrobiną przygody, emocji i fantazji życie. 


\section{Turystyka}

Słowo turystyka należy do obiegowych pojęć prawie wszystkich krajów współczesnego świata, jednak nie ma jednej powszechnie przyjętej definicji. Tadeusz Waldemar Gierat stwierdza, że „trudno jednoznacznie powiedzieć skąd wywodzi się termin "turystyka». Przyjmuje się, że geneza tego pojęcia sięga XVIII wieku i najprawdopodobniej ma związek z określeniem "grand tour». Oznaczało ono popularne w tamtych czasach wśród młodych Anglików wyjazdy na kontynent, odbywane przez nich w celach poznawczych, ale również dla rozrywki” (Gierat, 2013, s. 89). W szerszym znaczeniu, które prezentuje Międzynarodowy Słownik Turystyczny, turystyka to „podróże odbywane dla przyjemności, wypoczynku lub leczenia - pieszo lub jakimkolwiek środkiem lokomocji” (Gierat, 2012a, s. 226). Z zakresu tego pojęcia wyłączone zostają wyjazdy motywowane zarabianiem pieniędzy lub zmianą miejsca zamieszkania na stałe. Tematem turystyki zainteresowanych jest wielu specjalistów, którzy tworzą różne pojęcia i definicje, biorąc pod uwagę wiele różnych jej aspektów (Trojniel, 2007, s. 11). Ponieważ w literaturze możemy znaleźć wiele różnorodnych definicji, ograniczę się do przytoczenia kilku moim zdaniem najbardziej trafnych. Zgodnie z definicją Światowej Organizacji Turystyki (World Tourist Organization, WTO), turystyka to ogół czynności osób, które podróżują i przebywają w celach wypoczynkowych, zawodowych lub innych, nie dłużej niż rok bez przerwy poza swoim codziennym otoczeniem, z wyłączeniem wyjazdów, w których głównym celem jest aktywność zarobkowa. Turystyka jest formą czynnego wypoczynku poza miejscem stałego zamieszkania (Wikipedia). Istotą turystyki jest ruch i zmiana miejsca, tak więc przez turystykę rozumiemy ogół zjawisk związanych z czasową zmianą środowiska, wynikającą z motywów poznawczych, rekreacyjnych, dokonywaną w czasie wolnym (Denek, 1989, s. 10).

W ujęciu Kazimierza Denka turystyka oznacza: „zorganizowane zbiorowe lub indywidualne wyjazdy poza miejsce stałego zamieszkania, wędrówki po obcym terenie, mające cele krajoznawcze lub będące formą czynnego wypoczynku” (tamże, s. 10). Turystyka odgrywa ważną funkcję w zaspokojeniu potrzeb rekreacyjnych i zdrowotnych ludzi, ich zainteresowań i upodobań. Turystyka związana jest z rekreacją i czasem wolnym, przez co wiąże się również z zaspokajaniem potrzeb kulturalnych, twórczych i wyrabianiem aktywności.

W literaturze często przytaczana jest klasyczna definicja turystyki sformułowana przez szwajcarskiego ekonomistę Waltera Hunzikera. Uważa on, że turystyka to „zespół stosunków i zjawisk, które wynikają z podróży i pobytu osób przejezdnych, o ile nie następuje w związku z tym osiedlenie i podjęcie pracy zarobkowej" (Trojniel, 2007, s. 11). Definicja ta w pewnym stopniu jest zgodna z perspektywą 
ekonomiczną, w której turystyka to rynek, a turysta to konsument usług turystycznych, takich jak: noclegi, zakup pamiątek, pozyskiwanie informacji.

W bardzo ciekawy sposób przedstawia turystykę Kazimierz Wojciechowski. Jest to według niego forma aktywności poznawczej człowieka, która ma założone cele i wywołuje pewne skutki. Przez „turystykę rozumiemy podróżowanie szlakami ciekawymi lub podróżowanie do miejsc interesujących pod względem przyrody, historii, pamiątek przeszłości, gospodarki, podróżowanie podejmowane dla odpoczynku, zdrowia, odwiedzin bądź zaspokojenia bezinteresownej ciekawości lub chęci przeżycia. Turystyka mieści się w ramach wczasów, niesie odpoczynek, jest czynnikiem higieny psychicznej oraz kształci umysłowo, estetycznie, społecznie, uczuciowo, fizycznie" (tamże, s. 11).

Różnorodność definicji turystyki ukazuje jej interdyscyplinarny charakter. Z przeglądu definicji turystyki wynika, że powtarzają się w nich określenia takie jak: dobrowolna zmiana miejsca pobytu, zmiana miejsca w przestrzeni, podróż i pobyt czasowy poza miejscem stałego zamieszkania. Według autorów, psychologiczne podejście do turystyki musi brać pod uwagę stan świadomości turysty: jego motywy i percepcję podróży. Turysta to osoba, dla której ważniejszy jest wyjazd i przebywanie poza domem niż tego skutki. Największe znaczenie ma subiektywna ocena i fakt, że dana osoba chce być turystą, a nie kryteria formalne, takie jak środek transportu, rodzaj i czas trwania wyjazdu (Winiarski, Zdebski, 2008, s. 14).

Wyróżniamy różne formy turystyki i ich kategoryzacje, np. z uwagi na czas trwania, rodzaj środka lokomocji, cel, liczbę uczestników, miejsce zamieszkania.

Wyróżniono następujące rodzaje turystyki: turystyka kwalifikowana i obozy wędrowne; turystyka krótko- i długoterminowa; agroturystyka; ekoturystyka; turystyka aktywna; turystyka biznesowa; turystyka edukacyjna; turystyka górska; turystyka kolejowa i autokarowa; turystyka konna; turystyka kulturowa; turystyka medyczna, w tym aborcyjna; turystyka motorowa; turystyka rowerowa; turystyka piesza; turystyka uzależnień; turystyka wodna; turystyka zniszczeń; turystyka erotyczna; turystyka śmierci; turystyka handlowa; turystyka religijna i pielgrzymkowa.

Turystyka ma duże znaczenie w procesie samokształcenia, czyli uczenia się pewnych wzorców przeżywania, zachowania społecznego, myślenia. Dzięki temu zaspokaja potrzeby poznawcze, zdrowotne, rekreacyjne i ludyczne człowieka (Błażejczyk, 2008, s. 10). Procesy te w sposób pozytywny wpływają na rozwój osobowości. Dzięki turystyce możemy też pogłębić swoją wiedzę o kraju i środowiskach kulturalnych oraz stworzyć własną ocenę światopoglądową. Samokształcenie, w jakim uczestniczymy podczas udziału w wycieczkach turystycznych, jest wysoce skuteczne, ponieważ angażujemy w jego trakcie myślenie, emocje i wyobraźnię.

Podczas rozważań nad aktywnością turystyczną ważnym aspektem pozostaje problematyka motywacji. Jak stwierdza Carl Rogers, człowieka charakteryzuje 
głównie jeden motyw: wzrostu, rozwoju, osiągnięcia, poczucia spełnienia, a aktywność turystyczna daje możliwość jego realizacji. W nawiązaniu do aktywności turystycznej John Crompton wymienia następujące motywy jej podejmowania: ucieczka od otaczającego przyziemnego świata; doświadczanie i ocena; relaks; prestiż; powrót; wzmacnianie więzi rodzinnych; nawiązywanie interakcji społecznych; nowatorstwo, nowość; uczenie się (Winiarski, Zdebski, 2008, s. 49).

Natomiast Robert W. McIntosh i Charles R. Goeldner uznali za najważniejsze następujące czynniki, które są motywacją do podróżowania:

> fizyczne - czyli uprawianie sportów, wypoczynek, odprężenie i rozrywka;

$>$ kulturalne - chęć poznawania innych stron świata, ich kultury, zabytków, religii;

$>$ interpersonalne - poznawanie nowych osób, odwiedzanie przyjaciół, rodziny;

$>$ statusu i prestiżu - wynikające z wewnętrznych potrzeb człowieka i obejmujące ogólny rozwój osobowości, poszerzenie wiedzy o świecie (tamże, s. 49-50).

Turystyka jest dynamicznie rozwijającym się zjawiskiem współczesnej kultury, dlatego też zajmuje ważne miejsce w sferach: społecznej, ekonomicznej, psychologicznej, przestrzennej oraz kulturowej. Poprzez to turystyka pełni określone funkcje. W literaturze przedmiotu odnaleźć można wiele różnych podejść dotyczących funkcji turystyki (Trojniel, 2007, s. 12).

Jedną z nich przedstawia Władysław Gaworecki, który wymienia następujące funkcje turystyki:

$\checkmark$ funkcja wypoczynkowa - wypoczynek jest bardzo ważny, aby człowiek mógł dobrze funkcjonować w życiu prywatnym i zawodowym;

$\checkmark$ funkcja zdrowotna - istotne dla miejsca wypoczynku są walory zdrowotne, dzięki którym możemy zyskać energię i dobre samopoczucie;

$\checkmark$ funkcja wychowawcza-uwzględnia kontakt turysty z przyrodą, kulturą, życiem społecznym i mieszkańcami odwiedzanych miejsc;

$\checkmark$ funkcja kształceniowa - daje możliwość bezpośredniego poznania określonych rzeczy i zjawisk oraz wykorzystania swoich umiejętność w praktyce oraz poszukiwania nowych wiadomości;

$\checkmark$ funkcja miastotwórcza - turystyka przyspiesza procesy urbanizacyjne, a urbanizacja wpływa na tempo i kierunki rozwoju turystyki;

$\checkmark$ funkcja edukacji kulturowej - łączy się z wychowaniem i kształceniem, pogłębianiem wiedzy oraz konfrontacją wiedzy z praktyką;

$\checkmark$ funkcja ekonomiczna - wiąże się z wymianą pieniędzy oraz powstawaniem nowych biur, ośrodków i instytucji, rozszerzeniem oferty sieci noclegowych, usług gastronomicznych itp.;

$\checkmark$ funkcja etniczna - podróże zagraniczne związane z miejscem pochodzenia lub poszukiwaniem swoich korzeni i przodków; 
$\checkmark$ funkcja kształtowania świadomości ekologicznej - jest ściśle związana z turystyką, a ponieważ walory przyrodnicze są największą atrakcją turystyczną i przyciągają wielu odwiedzających, przyczynia się do niszczenia środowiska naturalnego; $\checkmark$ funkcja polityczna - turystyka łączy elementy kultury, historii, ułatwia nawiązywanie kontaktów, współpracę i integrację wielu państw (Gaworecki, 1997, s. 57-60).

\section{Turystyka seniorów}

Turystyka odgrywa bardzo ważną rolę w życiu człowieka, w tym także seniora. Dzięki niej może zobaczyć on pewne rzeczy i zjawiska z innej perspektywy, doświadczyć czegoś cennego i wartościowego. Głównym źródłem turystyki jest chęć poznawania otaczającego nas świata. Dzięki tej formie aktywności człowiek może zrealizować swoje potrzeby, zdobyć wiedzę, rozszerzyć horyzonty, poznać nowych ludzi oraz odmienne kultury i tradycje, doznać nowych wrażeń, ożywić uczucia oraz zaspokoić potrzebę aktywności, twórczości oraz wiele innych.

„Organizacje pozarządowe z sektora turystyki aktywnie włączają się w realizację na rzecz rozwoju turystyki społecznej, w tym wzrostu uczestnictwa w turystyce osób starszych" (Pikuła, 2013, s. 167). Niemniej w okresie późnej dorosłości można zaobserwować duży spadek aktywności turystycznej. Może to być spowodowane pogorszeniem sprawności fizycznej i ogólnego stanu zdrowia. Jak wykazują badania Jerzego Łaciaka z 2005 roku, tylko 29,1\% osób w wieku starszym brało udział w wyjazdach turystycznych (Winiarski, Zdebski, 2008, s. 34-35). Dla porównania, „uczestnictwo w ruchu turystycznym w 2014 roku deklarowało już 37,4\% ludności w starszym wieku. Aktywność turystyczna jak pokazują dane statystyczne koncentruje się przede wszystkim w okresie miesięcy urlopowo wakacyjnych. Najczęściej były to wyjazdy do znajomych i rodziny, rzadziej turystyczno wypoczynkowe i sanatoryjne" (Parzych, Gotowski, 2019, s. 685-686). Natomiast w badaniach z 2016 roku „znaczna część badanych $(66,8 \%)$ w trakcie ostatnich 12 miesięcy zdecydowała się jednak na wyjazd o charakterze turystycznym. 37,4\% spośród tego grona odbyło 1 podróż, $27,9 \%$ - 2 podróże, a 22,8\% wyjeżdżało trzy razy. Osoby, które odbyły cztery i więcej wyjazdów stanowiły 11,9\% grupy aktywnych turystycznie respondentów" (Zawadka, 2016, s. 122). Dane te pokazują specyfikę korzystania z formy rekreacji, jaką jest turystyka. Zauważamy, że w wieku senioralnym nasilenie wyjazdów turystycznych w porównaniu do populacji osób dorosłych jest znacząco mniejsze. „W grupie osób powyżej 65 roku życia mniej więcej co piąta osoba starsza wyjechała w celach turystycznych, wypoczynkowych. Dla porównania - w całej populacji wyjechały w tym czasie 2 osoby na 5" (Górna, 2015, s. 157). 
To zaprzestawanie czynnego uprawiania turystyki jest zgodne z teorią wycofania się Elaine Cumming i Williama Henry’ego, która wyjaśnia mechanizm adaptacji do starości. Teoria ta mówi, że dla ludzi starszych charakterystyczny styl życia to tzw. „styl bujanego fotela”, który łączy się z odpoczynkiem, refleksją, dystansem do codziennego pośpiechu. „Starzenie się organizmu jest uwarunkowane genetycznie, jednak poprzez czynniki zewnętrzne może być ono opóźnione lub przyspieszone. Turystyka jest takim czynnikiem, który zapobiega starzeniu się poprzez aktywność fizyczną. Niedobór ruchu prowadzi do przyspieszenia procesów starzenia się oraz niedołęstwa fizycznego, a pośrednio także psychicznego" (Gierat, 2013, s. 91). Ograniczenie lub rezygnacja z aktywności turystycznej jest w obecnych czasach związana również z gorszą sytuacją materialną osób, które kończą pracę zawodową i przechodzą na emeryturę. Jednak opisana powyżej teoria nie odnosi się do wszystkich seniorów. Niektórzy ludzie starsi mimo wieku wcale nie rezygnują z czynnego uprawiania turystyki, a obniżają jedynie jej intensywność i stopień trudności. Zachowanie tej grupy osób w starszym wieku jest odzwierciedleniem teorii aktywności, która wyjaśnia proces adaptacji do starości. Według tej teorii osoby starsze chcą zestarzeć się optymalnie i w dalszym ciągu czerpać radość z życia, poprzez zachowanie aktywności i utrzymywanie więzi społecznych. Tendencje te można zaobserwować w turystyce szczególnie bogatych społeczeństw Europy Zachodniej, Ameryki Północnej oraz Japonii. Można mieć nadzieję, że również nasz kraj w szerszym stopniu obejmą podobne trendy.

Turystyka, a szczególnie turystyka kwalifikowana, posiada wartości psychoprofilaktyczne, terapeutyczne i zdrowotne. Korzystnie działa na psychikę jednostki, sprzyja sytuacji relaksu i odprężenia. W dzisiejszej cywilizacji aktywność ta zmniejsza się, co jest powodem obniżenia odporności organizmu i przeciążenia układu nerwowego. Natomiast poprzez wysiłek fizyczny, zwłaszcza w naturalnym środowisku przyrodniczym, możemy poprawić swoje samopoczucie. Aktywność turystyczna daje możliwość zmiany środowiska przestrzennego i społecznego. W grupie turystycznej nie występują konflikty, takie jak w życiu codziennym, ponieważ spotykają się tu osoby o podobnych zainteresowaniach, które nie rywalizują ze sobą i nie są związane formalnymi układami i zależnościami, a to sprzyja redukcji napięć oraz wyzwala pozytywne stany emocjonalne. Turystyka wpływa na pojawienie się nowych zainteresowań i pasji, dzięki którym osoby starsze mogą zobaczyć nowy sens swojego życia. Może pełnić także funkcję katartyczną, co pozwala danej osobie na refleksję i odreagowanie problemów oraz zyskanie dystansu do nich. Dzięki uprawianiu turystyki osoby starsze mogą utrzymać, a nawet poprawić swoje zdrowie. Poprzez racjonalne uprawianie turystyki można spowolnić proces starzenia się organizmu oraz poprawić jakość „jesieni życia” (tamże, s. 107-110). Jednym z rodzajów turystyki szczególnie popularnym w grupie seniorów jest turystyka piel- 
grzymkowa, inaczej zwana religijną. Podróż taka jest podejmowana z pobudek religijno-poznawczych. Osoby biorące udział w turystyce pielgrzymkowej, podobnie jak inni turyści, korzystają z tych samych elementów infrastruktury turystycznej oraz środków transportu. Różni ich jednak cel podróży oraz zachowanie w miejscu docelowym. Pielgrzymi udają się do miejsc uważanych za święte, ze względu na szczególne działanie tam Boga lub innej siły wyżzzej. Wyznawcy wszystkich religii uważają za ważne pielgrzymowanie do miejsc kultu religijnego, jednak aż $2 / 3$ pielgrzymów to chrześcijanie, którzy udają się do sanktuariów i miejsc słynących z łask i cudów (Wrona, 2012, s. 21).

Również praktyka geriatryczna wskazuje na bardzo korzystny wpływ turystyki na profilaktykę i leczenie osób w starszym wieku. T.W. Gierat zauważa, że „turystyka jest formą działalności, która może pomóc starszemu człowiekowi wyrwać się z bezruchu i izolacji społecznej, ułatwić pielęgnowanie zdrowia, utrzymać na wysokim poziomie sprawność i odnaleźć ponownie sens życia" (Gierat, 2012b, s. 156). Jak wynika z podanego powyżej stwierdzenia uprawianie turystyki przynosi wiele korzyści. Analizując rolę turystyki w życiu człowieka starszego, trzeba wyodrębnić jej trzy płaszczyzny: psychiczną, fizyczną oraz społeczną. Aktywność fizyczna jaką wykonuje osoba starsza podczas uprawiania turystyki, jest jednym z czynników zapobiegających procesowi starzenia się. Niedobór ruchu powoduje natomiast osłabienie odporności organizmu, nasila rozwój chorób, pośrednio obniża sprawność psychiczną. Sprawność i wydolność fizyczna seniora zależy od: wydolności fizycznej osiągniętej do 25 r.ż.; aktywności fizycznej w wieku dojrzałym; zmian organicznych i czynnościowych, jakie powstają w wyniku przebytych chorób i różnych sprowadzonych przez cywilizację czynników szkodliwych (tamże).

Z powyższych stwierdzeń wynika, iż sprawność fizyczna seniora jest zależna np. od jego trybu życia i aktywności fizycznej, jaką podejmował we wcześniejszych fazach życia. Nawet u osób z obniżoną wydolnością można ją podwyższyć dzięki uprawianiu turystyki, która skłania do aktywności ruchowej. Nie da się osiagnnąć tego celu bez świadomości, jak ważne jest uprawianie turystyki dla całego społeczeństwa. Dla osób starszych szczególnie polecana jest turystyka kwalifikowana, dlatego że seniorzy są bardziej aktywni podczas spaceru na łonie natury lub zwiedzając ciekawe miejsca niż np. w czasie regularnych ćwiczeń fizycznych. Do podejmowania aktywności fizycznej motywuje ich atrakcyjność danego terenu, możliwość wędrowania, pływania. Dzięki możliwościom, jakie daje dostosowanie wysiłku do możliwości fizycznych i zdrowotnych uczestników, większość seniorów wybiera tę formę aktywności. Wynika to z faktu, że ludzie starsi uważają ją za stosunkowo korzystną i dostępną oraz sprzyjającą dobremu samopoczuciu i zapobiegającą wielu chorobom cywilizacyjnym. 
Bardzo istotna dla ludzi w podeszłym wieku jest turystyka zdrowotna, która daje możliwość korzystania z różnych zabiegów i urządzeń leczniczych.

Nie można jednak zapomnieć, iż nie wszystkie formy turystyki będą wpływały korzystnie na samopoczucie fizyczne seniora. Zależy ono m.in. od jego stanu zdrowia, sprawności i wytrzymałości. W związku z powyższym podczas dobierania form aktywności fizycznej dla osób starszych trzeba zachować szczególną wnikliwość i rozwagę. Osoby o słabej kondycji nie powinny brać udziału w forsownych odmianach aktywności fizycznej (tamże, s. 157-158). Z turystyką i podróżowaniem związane są pewne zagrożenia, np. urazy narządów ruchu, które zdarzają się osobom aktywnie spędzającym czas i zarażenia różnymi chorobami, zwłaszcza podczas podróży zagranicznych. Bardzo ważne jest, aby osoby przewlekle chore, które zażywają leki, dokładnie przemyślały i zaplanowały dłuższe wycieczki. Dla osób cierpiących na alergie lepszym rozwiązaniem jest urlop w okresie zimowym niż letnim czy wiosennym. Natomiast dla osób ze schorzeniami nerwicowymi i różnymi formami depresji wskazane jest przebywanie w ciepłym i słonecznym klimacie. W kurortach górskich seniorzy mogą wzmocnić swoją odporność i wytrzymałość organizmu. Pobyt w górach nie jest jednak zalecany dla osób chorujących na nadciśnienie tętnicze krwi, chorobę niedokrwienną serca czy zapalenie oskrzeli. Z kolei odpoczynek w uzdrowiskach górskich korzystnie wpływa na przebieg takich schorzeń, jak kamica nerkowa czy choroba zwyrodnieniowa stawów (Żukowska-Kowalska, Jóźków, Mędraś, 2005, s. 5-6). Bardzo istotnymi elementami przed zaplanowaniem podróży, szczególnie u osoby w podeszłym wieku, jest:

$\checkmark$ kontrola lekarska przed wyjazdem;

$\checkmark$ przygotowanie dokumentacji medycznej chorób i spisu przyjmowanych leków;

$\checkmark$ zaopatrzenie w potrzebne leki;

$\checkmark$ ubezpieczenie medyczne;

$\checkmark$ szczepienia ochronne - podczas podróży zagranicznych;

$\checkmark$ przygotowanie apteczki podróżnej (tamże, s. 6-15).

Pamiętając o wyżej wymienionych zaleceniach unikniemy kłopotów i zagrożeń podczas podróży, a uprawianie turystyki będzie przyjemne i bezpieczne.

\section{Zakończenie}

Podsumowując można stwierdzić, iż turystyka ma bardzo pozytywny wpływ na seniorów, którzy poprzez udział w aktywności ruchowej hamują proces starzenia się organizmu i poprawiają swoje samopoczucie psychiczne. Podejmując różne formy aktywności ruchowej oddziałują na trzy podstawowe elementy bezpośrednio wpływające na kondycję zdrowotną, a mianowicie: poprawiają wydolność tlenową 
(aerobowa), wzmacniają siłę mięśni oraz poprawiają gibkość, równowagę i koordynację ruchów. Zakres podejmowanych działań rekreacyjnych jest w dużym stopniu zindywidualizowany i zależy od zdrowia i sprawności. Aktywność ruchowa w wieku senioralnym ma na celu:

- kształtowanie odpowiedniej postawy wobec świata;

- umożliwianie nawiązywania kontaktów towarzyskich;

- wpływanie na poprawę stanu zdrowia, stopnia sprawności fizycznej czy ogólnej aktywności życiowej;

- oraz wywieranie korzystnego wpływu na sferę psychiczną i duchową.

Uczestnicząc w aktywności turystycznej, seniorzy mogą zmienić na jakiś czas swoje miejsce pobytu, np. na ciche i spokojne środowisko będące bliżej natury, co z pewnością ma dobroczynny wpływ na psychikę (Gierat, 2012b, s. 158-159). Poprzez turystykę ludzie starsi mogą zrealizować swoje pasje i marzenia, poszerzyć system wartości, opierając go na doznaniach kulturalnych i estetycznych. Mogą urozmaicać swoje życie, odrywając się od codziennej rutyny, a często i samotności.

Turystyka pozwala zdobyć nowe wiadomości o świecie, dzięki czemu człowiek rozwija się i posiada większą świadomość otoczenia, wzmacnia swoje poczucie wartości oraz pewności siebie. Człowiek starszy dzięki aktywności turystycznej wolniej się starzeje i dłużej pozostaje sprawny. Można powiedzieć, iż jest to pewna forma terapii, która aktywizuje myślenie, ułatwia nawiązywanie kontaktów interpersonalnych, zapobiega samotności. Turystyka powinna być stałym elementem zdrowego i aktywnego stylu życia ludzi starszych.

\section{Bibliografia}

Banach B., Banach M. (2015a). Wykorzystanie pedagogiki zabawy KLANZA w pracy z seniorami. W: K. Jagielska, A. Mirczak (red.), Starzejemy się $w$ dobrym stylu. Kraków: Wydawnictwo Scriptum.

Banach B., Banach M. (2015b). Zabawa w życiu cztowieka. W: K. Jagielska, A. Mirczak (red.), Starzejemy się w dobrym stylu. Kraków: Wydawnictwo Scriptum. Błażejczyk G. (2008) Turystyka jako forma aktywności fizycznej. Walory poznawcze i wychowawcze naszego kraju. „Lider” 2008, nr 10.

Denek K. (1989). Krajoznawstwo i turystyka w wychowaniu dzieci i mtodzieży szkolnej. Warszawa: Wydawnictwo PTTK „Kraj”.

Gaworecki W. (1997). Turystyka. Warszawa: PWE.

Gierat T.W. (2013). Organizacja i zalecane formy turystyki dla osób starszych. W: J. Matejek, E. Zdebska (red.), Senior w rodzinie i instytucji spotecznej. Kraków: Iris Studio. 
Gierat T.W. (2012a). Spoteczno- wychowawcze aspekty dziatalności krajoznawczo- turystycznej. W: M. Banach, J. Matejek (red.), $Z$ teorii i praktyki pracy socjalnej. Levoča: Wydawnictwo MTM.

Gierat T.W. (2012b).Organizacja i formy turystyki osób starszych. W: N. Pikuła (red.), Starość może być atrakcyjna. Kraków: Wydawnictwo Scriptum.

Górna J. (2015). Preferencje i aktywność turystyczna Polaków w wieku 50+. Prace Naukowe Akademii im. Jana Długosza w Częstochowie, Kultura Fizyczna, t. XIV, nr 1.

https://encyklopedia.pwn.pl/haslo/rekreacja;3966939.html, dostęp z dn. 25.10.2019.

Madejski E., Węglarz J. (2008). Wybrane zagadnienia wspótczesnej metodyki wychowania fizycznego. Podręcznik dla nauczycieli i studentów,, Kraków: Impuls

Okoń W. (1996). Nowy stownik pedagogiczny. Warszawa: Wydawnictwo Akademickie Żak.

Parzych K., Gotowski R. Determinanty aktywności turystycznej osób starszych w Polsce na tle innych krajów europejskich, http://ojs.ukw.edu.pl/index.php/johs/article/view/4116, s.685-686, dostęp z dn. 25.10.2019.

Pikuła N. (2013). Senior w przestrzeni spotecznej. Warszawa: Wydawnictwo Borgis. Rynkowska D. Rola i znaczenie aktywności w życiu cztowieka starszego. W: https:// www.pulib.sk/web/kniznica/elpub/dokument/Husar7/subor/Rynkowska.pdf, (dostęp z dn. 20.12.2019).

Trojniel S. (2007). Turystyka - pojęcie, próby definicji, funkcje turystyki. „Lider”, nr 78.

Winiarski R. (2011). Wprowadzenie do zagadnień rekreacji i czasu wolnego. W: R. Winiarski (red.), Rekreacja i czas wolny: Studia humanistyczne. Warszawa: Oficyna Wydawnicza Łośgraf.

Winiarski R., Zdebski J. (2008). Psychologia turystyki. Warszawa: Wydawnictwa Akademickie i Profesjonalne.

Wrona J. (2012). Turystyka pielgrzymkowa. „Geografia w Szkole”, nr 4.

www.wikipedia.pl., dostęp z dn. 25.10.2019.

Zawadka J. (2016). Charakterystyka aktywności turystycznej seniorów w Polsce. „Ekonomiczne Problemy Turystyki”, nr 2(34).

Zdebska E. (2014). Aktywność osób starszych a zdrowie. W: N. Pikuła (red.), Warsztaty edukacyjne seniora. Kraków: Wydawnictwo Scriptum.

Żukowska-Kowalska K., Jóźków P., Mędraś M. (2005). Medyczne aspekty turystyki i rekreacji. Wrocław: Wydawnictwo AWF

Żukowska Z. (2006). Rekreacja fizyczna. W: T. Pilch (red.), Encyklopedia pedagogiczna XXI wieku, Tom V, R-St. Warszawa: Wydawnictwo Akademickie Żak. 
Tourism and recreation - a form of physical activity for the elderly

\begin{abstract}
Nowadays, the issue of the health of the aging society is becoming more and more important. We are beginning to appreciate the importance of physical activities in relation to the health condition of society. There is a significant number of diverse forms of activities addressed to seniors. One of them is tourism, which is the most common form of recreation, in particular - physical recreation. In the article, I present theoretical aspects of the importance of recreation and tourism for the health of seniors.
\end{abstract}

Keywords: recreation, tourism, physical activity, seniors 